\title{
PERTANGgUNGJAWABAN ADMINISTRATIF PENGELOLAAN \\ LINGKUNGAN HIDUP BERBASIS PARTISIPASI MASYARAKAT UNTUK PEMBANGUNAN BERKELANJUTAN DI BALI
}

\author{
I Nyoman Gede Sugiartha ${ }^{1)}$, Putu Wisnu Nugraha ${ }^{2)}$ \\ ${ }^{1) 2}$ Fakultas Hukum Universitas Warmadewa Denpasar \\ Email: nyomansugiartha14@gmail.com ${ }^{1)}$
}

\begin{abstract}
A good and healthy environment is a human right of every Indonesian citizen as mandated in Article $28 \mathrm{H}$ of the 1945 Constitution of the Republic of Indonesia. Indiscriminate environmental management contributes to the deterioration of the quality of the environment, therefore it is necessary to increase environmental protection and management. The protection and sustainable management of the environment is the responsibility of the government and the community. The government's responsibility in protecting and managing the environment is a function of public services, to ensure that all residents have a good and healthy environment. Then the government can be held accountable, both administratively, civilly and criminally when the government neglects to carry out its obligations that are not in accordance with the aspirations of the community. This research is qualified as a normative legal research by applying several types of approaches, namely, a statutory approach, a conceptual approach, a philosophical approach, a historical approach, a comparative approach, a case approach including a cultural approach based on local community wisdom. Therefore, this study aims to find philosophical and theoretical thoughts based on local wisdom about the nature of integrating community aspirations in the enforcement of Environmental Law both in administrative law, civil law and criminal law.

The results of the study show that environmental protection and management is an effort to carry out responsibilities, which is very difficult, resulting in a decrease in the quality of the environment. Therefore, law enforcement is to make improvements to the applicable rules through the politics of normative legislation, then followed by administrative law enforcement. However, participatory environmental enforcement by integrating the values that develop in the community in protecting and preserving the environment is an ideal form to protect and manage the environment wisely to realize sustainable regional development.
\end{abstract}

Keywords: Accountability, community, environment, law enforcement Abstrak

Lingkungan hidup yang baik dan sehat merupakan hak asasi setiap warganegara Indonesia sebagaimana diamanatkan dalam Pasal 28H UUD RI 1945. Pengelolaan lingkungan yang kurang bijaksana turut memperparah penurunan kwalitas lingkungan hidup karena itu perlu dilakukan peningkatan 
perlindungan dan pengelolaan lingkungan hidup. Perlindungan dan pengelolaan lingkungan yang berkelanjutan merupakan tanggungjawab pemerintah beserta masyarakat. Pertanggungjawaban pemerintah dalam melakukan perlindungan dan pengelolaan lingkungan hidup merupakan fungsi pelayanan public, untuk menjamin seluruh penduduk mendapatkan lingkungan yang baik dan sehat. Maka pemerintah dapat diminta pertanggungjawabannya, baik secara administrative, perdata maupun pidana mana kala pemerintah lalai melaksanakan kewajibannya yang tidak sesuai dengan aspirasi masyarakat. Penelitian ini dikualifikasikan sebagai penelitian hukum normatif dengan menerapkan beberapa jenis pendekatan yaitu, pendekatan perundang-undangan, pendekatan konseptual, pendekatan filsafat, pendekatan sejarah, pendekatan perbandingan, pendekatan kasus termasuk pula pendekatan budaya atas dasar kearifan masyarakat lokal. Oleh karena itu, penelitian ini bertujuan menemukan pemikiran filosofis dan teoritis berbasis kearifan lokal tentang hakikat pengintegrasian aspirasi masyarakat dalam penegakan Hukum Lingkungan baik secara hukum administratif, hukum perdata maupun hukum pidana.

Hasil penelitian menunjukan bahwa perlindungan dan pengelolaan lingkungan hidup adalah upaya mengemban tanggungjawab sangat sulit sehingga mengakibatkan terjadinya penurunan kwalitas lingkungan hidup makin nyata. Oleh karenanya maka penegakan hukum adalah melakukan penyempurnaan terhadap aturan yang berlaku melalui politik legislasi penormaan selanjutnya baru diikuti penegakan hukum administrasif. Namun demikian penegakan lingkungan partisipatif dengan mengintegrasikan nilai-nilai yang berkembang di masyarakat dalam menjaga dan melestarikan lingkungan adalah suatu bentuk idial untuk melindungi dan melakukan pengelolaan lingkungan hidup secara bijaksana untuk mewujudkan pembangunan daerah yang berkelanjutan.

Kata kunci: Pertanggungjawaban, masyarakat, lingkungan, penegakan hukum.

\section{A. Pendahuluan}

Lingkungan hidup yang baik dan sehat merupakan hak asasi setiap warganegara Indonesia sebagaimana diamanatkan dalam Pasal 28H UUD RI 1945. Pengelolaan lingkungan yang kurang bijaksana turut memperparah penurunan kualitas lingkungan hidup

${ }^{1}$ Sudi Fahmi,2013, “Asas Tanggung Jawab Negara Sebagai Dasar Pelaksanaan Perlindungan dan Pengelolaan Lingkungan Hidup”, Jurnal Hukum, Vol. 18 No. 2 April, hal. 212-228 karena itu perlu dilakukan peningkatan perlindungan dan pengelolaan lingkungan hidup. ${ }^{2}$ Perlindungan dan pengelolaan lingkungan hidup bertujuan mewujudkan pembangunan berkelanjutan.

Melakukan perlindungan dan pengelolaan terhadap lingkungan hidup

\footnotetext{
2 Ohni Najwan, 2012,"Perlindungan dan Pengelolaan Lingkung-an Hidup dJalam Perspektif Hukum Islam”, Inovatif: Jur-nal Ilmu Hukum, Vol. 2 No. 4 , hal. 57
} 
yang baik dan sehat maka setiap pelaku dan/atau penanggung jawab usaha wajib mendapatkan izin lingkungan sesuai ketentuan hukum yang berlaku. Hal ini tertuang dalam Undang-undang Pengelolaan dan Perlindungan Lingkungan Hidup (UUPPLH) No. 32 Tahun 2009, Peraturan Pemerintah No. 27 Tahun 2012 tentang Izin Lingkungan, Peraturan Mentri Lingkungan Hidup No. 08 Tahun 2013 Tentang Tata Laksana Penilaian Dan Pemeriksaan Dokumen Lingkungan Hidup Serta Penerbitan Izin Lingkungan. Izin lingkungan adalah sesuatu yang wajib dimiliki oleh penanggungjawab usaha dan /atau kegiatan sebagai upaya pengawasan dari pemerintah dalam perlindungan dan pengelolaan lingkungan hidup. $^{3} \quad$ Upaya perlindungan lingkungan yang baik dan efektif adalah dengan penegakan hukum melalui jalur tiga jalur yaitu ; jalur administratif, jalur perdata dan jalur hukum pidana. Hukum diciptakan sebagai suatu sarana atau instrumen

${ }^{3}$ Dyah Adriantini Sintha Dewi, 2012, “ Konsep Pengelolaan Lingkungan Hidup, Menuju Kemakmuran Masyarakat", Jurnal Fakultas Hukum, Vol. 1 No. 1 Universitas Muhammadiyah Magelang .hal.21. untuk mengatur hak-hak dan kewajiban-kewajiban subjek hukum. ${ }^{4}$ Selain itu hukum berfungsi sebagai instrumen perlindungan bagi subjek hukum. Pelaksanaan hukum dapat berlangsung secara normal, damai tetapi dapat terjadi juga karena pelanggaran hukum. ${ }^{5}$

Hukum yang mengatur hubungan hukum antara pemerintah dengan warga negara adalah Hukum Administrasi Negara atau hukum perdata, tergantung dari sifat dan kedudukan pemerintah dalam melakukan tindakan hukum tersebut. ${ }^{6}$ Ketika pemerintah melakukan tindakan hukum dalam kapasitasnya sebagai wakil dari badan hukum, maka tindakan tersebut diatur dan tunduk pada ketentuan hukum

4 Kartono,2009, Penegakan Hukum Lingkungan Administratif Dalam UndangUndang Perlindungan dan Pengelolaan Lingkungan Hidup, Jurnal Dinamika Hukum, Vol.09 No. 3, Purwekerto : FH UNSOED, hal.32.

5 Philipus M, Hadjon , 1987, Perlindungan Hukum Bagi Rakyat Indonesia, Penerbit Bina Ilmu, Surabaya, hal.66

6 Sutrisno, 2013, "Politik Hukum Perlindungan dan Pe-ngelolaan Lingkungan Hidup”, Jurnal Hukum, No. 3 Vol. 18 Juli 2013, FH UII,hal.17. 
Jurnal Hukum Saraswati (JHS) Volume. 03, Nomor 02, (2021)

ISSN (Cetak) : 2715-758X ISSN (Online): 2720-9555

DOI: https://doi.org/10.36733/jhshs.v2i2

https://e-journal.unmas.ac.id/index.php/JHS

29

keperdataan, ${ }^{7}$ sedangkan ketika dalam UU No. 32 Tahun 2009 tentang

pemerintah bertindak sebagai pejabat, PPLHAL. Maka dalam upaya maka tindakan itu diatur dan tunduk memaksimalkan penegakan hukum pada Hukum Administrasi Negara. sepatutnya didukung oleh aturan yang Apabila ketentuan peran serta baik, pelaksana pihak pemerintah masyarakat dalam bentuk aspirasi secara sungguh-sungguhal. ${ }^{9}$ masyarakat dengan tegas telah Masalahnya kecendrungan pemerintah terakomodasi dalam ketentuan pasal 26 Daerah membangun fasilitas ekonomi Undang-undang No.32 Tahun 2009 tentang PPLH, maka bagi dengan mengekploitasi sumber daya alam dan lingkungan untuk mengejar pelanggarnya harus dikenakan sanksi sesuai tingkat kesalahannya. $^{8}$ Pada tahap penerapan ketentuan pasal 25 dan 26 UUPPLH dengan memberi ketentuan tentang peran serta dan tangggapan masyarakat terhadap rencana usaha dan/atau kegiatan, sehingga penerapanya nanti lebih efektif. Mengingat produk hukum yang ada saat ini belum memenuhi fungsi hukum yang di cita-citakan baik dari sisi keadilan, manfaat dan kepastianya.

Kepastian penerapan hukum lingkungan sulit diselesaikan dan kelemahan-kelemahan penormaan

7 Sudi Fahmi,2013,“Asas Tanggung Jawab Negara Sebagai Dasar Pelaksanaan Perlindungan dan Pengelolaan Lingkungan Hidup", Jurnal Hukum, hal.36.

${ }^{8}$ Hikmat Ramdhan, Yusran, 2003, Pengelolaan Sumber Daya Alam Dan Otonomi Daerah, Perspektif Kebijakan Dan Evaluasi Ekonomi, Alqaprint Jatinangor,hal.74.

Pendapatan Asli Daerah (PAD), dan kurang memperhatikan daya dukung kelestarian lingkungan Daerahnya. ${ }^{10}$ dan kurang taat aturan.

Adapun rumusan masalah yang akan dibahas berdasarkan pemaparan latar berlakang masalah di atas yaitu : 1). Pertanggungjawaban Administratif pemerintah dalam pengelolaan lingkungan hidup yang tidak sesuai dengan aspirasi masyarakat ?, 2) Akibat hukum terhadap pemerintah atas keputusan dalam pengelolaan lingkungan hidup yang tidak sesuai dengan partisipasi masyarakat di Bali. Tujuan dari penulisan penelitian ini

\footnotetext{
${ }^{9}$ Otto Soemarwoto, 1999, Analisis Mengenai Dampak Lingkungan, Gadjah Mada University Press, Cetakan Kedelapan, Yogyakarta. HAL.76.

10 Pitana,2004, Memperjuangkan Otonomi Daerah :Mencegah Sandyakalaning Pariwisata Bali, Pustaka Bali Post, Denpasar,hal.19.
} 
adalah : 1) untuk mengkaji, mengetahui dan menemukan jalan keluar dari akibat hukum terhadap pemerintah atas keputusan dalam pengelolaan lingkungan hidup yang tidak sesuai dengan partisipasi masyarakat. 2) Memberikan kontribusi pada pemerintah Propinsi Bali masukan berupa saran dan tanggapan atas pengelolaan lingkungan sedangkan untuk masyarakat akan dapat menikmati lingkungan yang baik dan sehat sesuai dengan hak-haknya.

\section{B. Metode Penelitian}

Metode penelitian hukum menurut jenisnya dapat dibedakan menjadi dua, yaitu:

Penelitian Hukum Normatif dan Penelitian Hukum Empiris. ${ }^{11}$ Jenis penelitian yang dilakukan dalam rangka penulisan ini adalah penelitian hukum gabungan antaran Normatif dan Empirik (Mike Method).

Pendekatan masalah yang digunakan meliputi beberapa jenis pendekatan sebagaimana disebutkandi bawah ini. Pendekatan Perundangundangan(Statute

\footnotetext{
${ }^{11}$ Bambang Waluyo, 1991Penelitian Hukum Dalam Praktek, (Jakarta: Sinar Grafika,), hal. 13
}

Approach),Pendekatan koseptual (conceptual approach), Pendekatan Kasus (case approach),

Sumber bahan hukum penelitian pada umumnya dibedakan antara bahan hukum yang diperoleh dari aturan perundang-undangan dan dari bahan-bahan teori-teoeri dan pendapat sarjana dan/atau ahli hukum. Metode penelitian hukum normatif hanya mengenal data sekunder saja. ${ }^{12}$ Data sekunder tersebut terdiri dari bahan hukum primer; bahan hukum sekunder; dan bahan hukum tersier. ${ }^{13}$

Tehnik pengumpulan bahan hukum dilakukan dengan hukum kartu (card system), pengumpulan bahan hukum dengan menggunakan kartu, dilakukan kegiatan membaca secara kritis analitis dan membuat catatancatatan yang diperlukan.

Setelah langkah pengumpulan bahan hukum primer dan bahan hukum sekunder dengan hukum kartu lengkap, dilanjutkan dengan proses analisis. Analisis terhadap hasil penelitian ini menggunakan alur logika dalam penelitian hukum normatif, yang

\footnotetext{
12 Amiruddin dan Zainal Asikin, Opcit, hal. 31

${ }^{13}$ Ibid.hal.118
} 
ditempuh melalui langkah-langkah sebagai diuraikan dibawah ini.

Langkah

pertama

mendiskripsikan (memaparkan), pada tahap ini diskripsi meliputi, isi dan struktur hukum positif. Tahap kedua adalah sistematisasi, dilakukan untuk memaparkan isi dan struktur atau hubungan heararkhis, antara aturanaturan hukum yang berhubungan agar dapat dipahami dengan baik.Tahap ketiga adalah, tahap eksplanasi, pada tahap ini dilakukan penjelasan ada analisis terhadap makna yang terkandung dalam aturan-aturan hukum sehubungan dengan isu hukum dalam penelitian ini, sehingga keseluruhannya membentuk satu kesatuan yang saling berhubungan secara logis.

\section{Pembahasan}

\section{1. Pertanggungjawaban} Administratif Pemerintah

Dalam Pengelolaan

Lingkungan Hidup Yang Tidak Sesuai Dengan

Aspirasi

\section{Masyarakat}

Melakukan berbagai tindakan (termasuk tindakan hukum) pemerintah harus bersandar pada asas legalitas. Tindakan hukum mengandung makna
31

penggunaan kewenangan dan didalamnya tersirat adanya kewajiban pertanggungjawaban. Tanggung jawab negara terhadap warga negara atau pihak ketiga dianut oleh hampir semua negara. Perspektif hukum publik, tindakan hukum pemerintahan itu selanjutnya dituangkan dalam dan dipergunakan beberapa instrumen hukum dan kebijakan seperti peraturan perundang-undangan, peraturan kebijakan, dan keputusan. ${ }^{14}$ Disamping itu, pemerintah juga sering menggunakan instrumen hukum keperdataan seperti perjanjian dalam menjalankan tugas-tugas pemerintahan. Setiap penggunaan wewenang dan penerapan instrumen hukum oleh pejabat pemerintahn pasti menimbulkan akibat hukum, karena memang tujuannya dimaksudkan adalah untuk menciptakan hubungan hukum dan akibat hukum.

Pejabat adalah seorang yang karena tugas dan wewenangnya bertindak sebagai wakil dari jabatan, yang melakukan perbuatan untuk dan atas nama jabatan. Sementara seseorang itu disebut atau

14 Dyah Adriantini Sintha Dewi, Op.Cit., hal.105. 
dikategorikan sebagai pejabat adalah ketika ia menjalankan kewenangan untuk atau atas nama jabatan. Berdasarkan keterangan di atas, tampak bahwa tindakan hukum yang dijalankan oleh pejabat dalam rangka menjalankan kewenangan jabatan atau melakukan tindakan hukum untuk dan atas nama jabatan, maka tindakannya itu dikategorikan sebagai tindakan hukum jabatan.

Mengenai pertanggungjawaban pejabat ada dua teori yang dikemukakan oleh Kraenburg dan Vegting, yaitu; pertama, fautes personalles, yaitu teori yang menyatakan bahwa kerugian terhadap pihak ketiga itu dibebankan kepada pejabat yang karena tindakannya itu telah menimbulkan kerugian, kedua, fautes de services, yaitu teori yang menyatakan bahwa kerugian terhadap pihak ketiga itu dibebankan pada instansi dari pejabat yang bersangkutan. ${ }^{15}$

Mengutip pendapat Logeman, hak dan kewajiban berjalan terus, tidak peduli dengan penggantian pejabat. Berdasarkan keterangan tersebut jelaslah bahwa pemikul tanggung jawab itu adalah jabatan. Oleh karena itu, ganti rugi juga dibebankan kepada instansi/jabatan, bukan kepada pejabat selaku pribadi. Sebagaimana dikatakan Kranenburg dan Vegting bahwa pertanggungjawaban dibebankan kepada korporasi (instansi, jabatan) jika suatu perbuatan melawan hukum yang dilakukan oleh pejabat itu bersifat objektif, dan pejabat yang bersangkutan tidak dibebani tanggungjawab jika tidak ada kesalahan subjektif. Sebaliknya pejabat atau pegawai itu dibebani tanggung jawab ketika ia melakukan kesalahan subjektif. ${ }^{16} \quad$ Untuk perbuatan melanggar hukum lainnya, hanya wakil yang bertanggungjawab sepenuhnya; ia telah menyalahgunakan situasi, dimana ia berada selaku wakil, dengan melakukan tindakan amoralnya sendiri terhadap kepentingan pihak ketiga. Dalam hal demikian, pejabat tersebut telah melakukan kesalahan subjektif atau melakukan mal administrasi.

Pertanggungjawaban

administrtif pemerintah dalam hal keputusannya tidak sesuai aspirasi masyarakat dalam hukum lingkungan telah diatur dalam UUPPLH 
khususnya dalam Pasal 91 tentang Hak

Gugat Masyarakat dalam hal masyarakat dirugikan, Pasal 92 tentang Hak gugat masyarakat yang tergabung dalam Organisasi Lingkungan Hidup dan Pasal 93 UUPPLH memberikan hak setiap orang dalam masyarakat dapat mengajukan gugatan administrasi terhadap keputusan pemerintah apabila :

a. badan atau pejabat tata usaha negara menerbitkan izin lingkungan

kepada usaha dan/atau kegiatan yang wajib amdal tetapi tidak

dilengkapi dengan dokumen amdal;

b. badan atau pejabat tata usaha negara menerbitkan izin lingkungan kepada kegiatan yang wajib UKLUPL, tetapi tidak dilengkapi dengan dokumen

UKL-UPL;dan/atau

c. badan atau pejabat tata usaha negara yang menerbitkan izin usaha dan/atau kegiatan yang tidak dilengkapi dengan izin lingkungan.
C. 2 .

Akibat

Hukum

Administratif Pemerintah

Atas Keputusan dalam

Pengelolaan Lingkungan

Hidup yang Tidak Sesuai

dengan

Partisipasi

Masyarakat.

Ada beberapa hal yang menjadi alasan warga negara harus mendapat perlindungan hukum dari tindakan pemerintah, sebagai bentuk pertanggung jawaban memberi perlindungan masyarakat yaitu:

a) Karena dalam berbagai hal warga negara dan badan hukum perdata tergantung pada keputusankeputusan pemerintah, seperti kebutuhan terhadap izin yang diperlukan untuk usaha perdagangan, perusahaan atau pertambangan. Karena itu warga negara dan badan hukum perdata perlu mendapat perlindungan hukum.

b) Hubungan antara pemerintah dan warga negara tidak berjalan dalam posisi sejajar, dan warga negara berada di pihak lemah dalam hal ini.

c) Berbagai perselisihan warga negara dengan pemerintah 


\begin{abstract}
berkenan dengan keputusan,
sebagai instrumen pemerintah

yang memiliki kewenangan

bersifat sepihak dalam

menentukan intervensi terhadap

kehidupan warga negara.

Di Indonesia perlindungan
\end{abstract}

hukum bagi rakyat akibat tindakan

hukum pemerintah ada beberapa

kemungkinan, tergantung dari

instrumen hukum yang digunakan

pemerintahal. Instrumen hukum

pemerintah yang lazim digunakan

adalah peraturan perundang-undangan

dan keputusan. Perlindungan hukum

akibat dikeluarkannya peraturan

perundang-undangan ditempuh melalui

Mahkamah Agung, dengan cara hak uji

materiil, sesuai dengan Pasal 5 ayat (2)

Tap MPR No. III/MPR/2000 tentang

Sumber Hukum dan Tata Urutan

Peraturan Perundang-undangan, yang

menegaskan bahwa "Mahkamah

Agung berwenang menguji peraturan

perundang-undangan di bawah

undang-undang".

Khusus mengenai peraturan perundang-undangan tingkat daerah, pembatalan sering diartikan dalam pembatalan secara spontan, yakni pembatalan atas dasar inisiatif dari organ yang berwenang menyatakan pembatalan, tanpa melalui proses peradilan. Pasal 145 UU No. 32 Tahun 2004 tentang Pemerintahan Daerah terdapat ketentuan sebagai berikut:

1) Perda disampaikan kepada pemerintah paling lama 7 hari setelah di tetapkan.

2) Perda sebagaimana dimaksud ayat (1) yang bertentangan dengan kepentingan umum dan/atau peraturan perundangundangan yang lebih tinggi dapat dibatalkan oleh pemerintahal.

3) Keputusan pembatalan Perda sebagaimana dimaksud pada ayat (2) ditetapkan dengan Peraturan Presiden paling lama 60 hari sejak di terimanya Perda sebagaimana dimaksud ayat (1).

4) Paling lama 7 hari setelah keputusan pembatalan sebagaimana dimaksud pada ayat (3), kepala daerah harus memberhentikan pelaksanaan Perda dan selanjutnya DPRD bersama kepala daerah mencabut Perda dimaksud.

5) Apabila

Provinsi/kabupaten/kota tidak dapat menerima keputusan pembatalan Perda sebagaimana dimaksud pada ayat (3) dengan alasan yang dapat dibenarkan oleh peraturan perundangundangan, kepala daerah dapat mengajukan keberatan kepada Mahkamah Agung.

6) Apabila keberatan sebagaimana dimaksud ayat (5) dikabulkan sebagian atau seluruhnya, 
putusan Mahkamah Agung tersebut menyatakan Peraturan Presiden menjadi batal dan tidak mempunyai kekuatan hukum.

7) Apabila Pemerintah tidak mengeluarkan Peraturan Presiden untuk membatalkan Perda sebagaimana dimaksud pada ayat (3), Perda tersebut dinyatakan berlaku.

Berdasarkan ketentuan tersebut, tampak bahwa peraturan perundangundangan tingkat daerah mempunyai mekanisme hak uji materil yang berbeda dengan peraturan perundangundangan tingkat pusat, yaitu di tempuh melalui jalur pemerintahan dalam bentuk penundaan atau pembatalan, sebelum ditempuh melalui Mahkamah Agung.

Perlindungan hukum akibat dikeluarkannya keputusan ditempuh melalui dua kemungkinan, yaitu peradilan hukum administrasi dan upaya hukum administrasif. Ada perbedaan antara peradilan hukum administrasi dan upaya administratif adalah kata peradilan menunjukkan bahwa hal ini menyangkut proses peradilan pada pemerintahan melalui instansi yang merdeka.

Berdasarkan UU No. 5 Tahun 1986 tentang Peradilan Tata Usaha
35

Negara perlindungan hukum akibat dikeluarkannya keputusan dapat ditempuh melalui dua jalur, yaitu melalui upaya administratif dan melalui PTUN. Dalam Pasal 48 di tegaskan sebagai berikut:

1) Dalam hal suatu Badan atau Pejabat TUN diberi wewenang oleh atau berdasarkan peraturan perundang-undangan untuk menyelesaikan secara administratif sengketa tata usaha negara tertentu, maka sengketa tata usaha negara tersebut harus diselesaikan melalui upaya administratif yang tersedia.

2) Pengadilan baru berwenang memeriksa, memutus dan menyelesaikan sengketa tata usaha negara sebagaimana dimaksud ayat (1) jika seluruh upaya administratif yang bersangkutan telah digunakan.

Upaya administratif ini ada dua macam, yaitu banding administratif dan prosedur keberatan. Banding administratif yaitu penyelesaian sengketa tata usaha negara dilakukan oleh instansi atasan atau instansi lain dari yang mengeluarkan keputusan yang disengketakan. Sedangkan prosedur keberatan adalah penyelesaian sengketa tata usaha negara dilakukan oleh instansi yang 
Jurnal Hukum Saraswati (JHS) Volume. 03, Nomor 02, (2021)

ISSN (Cetak) : 2715-758X ISSN (Online): 2720-9555

DOI: https://doi.org/10.36733/jhshs.v2i2

https://e-journal.unmas.ac.id/index.php/JHS

mengeluarkan keputusan yang

bersangkutan.

Ketentuan mengenai

penyelesaian sengketa tata usaha

negara melalui PTUN terdapat dalam

Pasal 53 ayat (1) UU No. 5 Tahun

1986 yang berbunyi:

seorang atau badan hukum perdata yang merasa kepentingannya dirugikan oleh suatu keputusan TUN dapat mengajukan gugatan tertulis kepada pengadilan yang berwenang yang berisi tuntutan agar keputusan TUN yang disengketakan itu dinyatakan batal atau tidak sah, dengan atau tanpa disertai tuntutan ganti rugi dan/atau rehabilitas.

Ketentuan Pasal 53 ayat (2) disebutkan mengenai tolok ukur untuk menilai KTUN yang digugat di PTUN, yaitu sebagai berikut:

1) Keputusan TUN yang digugat itu bertentangan dengan peraturan perundang-undangan yang berlaku

2) Badan atau pejabat TUN pada waktu mengeluarkan keputusan sebagaimana dimaksud dalam ayat (1) telah menggunakan wewenangnya untuk tujuan lain dari maksud diberikannya wewenang tersebut.

3) Badan atau Pejabat TUN pada waktu mengeluarkan atau tidak mengeluarkan keputusan sebagaimana dimaksud dalam ayat (1) setelah mempertimbangkan semua kepentingan yang tersangkut dengan keputusan itu seharusnya tidak sampai pada pengambilan keputusan tersebut.

Berdasarkan UU No. 9 tahun 2004 tentang Perubahan UU No. 5 tahun 1986 tentang PTUN, alasan mengajukan gugatan yang terdapat pada Pasal 53 ayat (2) ini ada perubahan, yaitu: Alasan-alasan yang dapat digunakan dalam gugatan sebagaimana dimaksud dalam ayat (1) adalah:

1) Keputusan TUN yang digugat itu bertentangan dengan peraturan perundang-undangan yang berlaku

2) Keputusan TUN yang digugat itu bertentangan dengan asas-asas umum pemerintahan yang baik.

Perubahan Pasal 53 ayat (2) ini memiliki konsekuensi:

2. Pengakuan eksistensi asas-asas umum pemerintahan yang baik (AAUPB) dalam sistem 
Jurnal Hukum Saraswati (JHS) Volume. 03, Nomor 02, (2021)

ISSN (Cetak) : 2715-758X ISSN (Online): 2720-9555

DOI: https://doi.org/10.36733/jhshs.v2i2

https://e-journal.unmas.ac.id/index.php/JHS

37

peradilan administrasi di Indonesia.

3. Ada perluasan alasan mengajukan gugatan ke PTUN. Asas larangan penyalahgunaan

wewenang dan asas larangan sewenangwenang merupakan bagian dari AAUPB.

Menurut Sjachran Basah $^{17}$, perlindungan hukum dan penegakan hukum merupakan qonditio sine qua non untuk merealisasikan fungsi hukum itu sendiri. Fungsi hukum yang dimaksud adalah sebagai berikut:

1. Direktif, sebagai pengarah dalam membangun untuk membentuk masyarakat yang hendak dicapai sesuai dengan tujuan kehidupan bernegara.

2. Integrative, sebagai Pembina kesatuan bangsa

3. Stabilitatif, sebagai pemelihara dan menjaga keselarasan, keserasian dan keseimbangan dalam kehidupan bernegara dan bermasyarakat.

4. Perfektif, sebagai penyempurna.

5. Korektif, sebagai pengoreksi atas sikap tindak baik administrasi

Negara maupun warga apabila terjadi pertentangan hak dan

kewajiban untuk mendapatkan keadilan.

Ada empat unsur sanksi dalam hukum administrasi negara, yaitu alat

17 Ridwan HR, Op.Cit., hal. 291 kekuasaan, bersifat hukum publik, digunakan oleh pemerintah, dan sebagai reaksi atas ketidak patuhan. Ditinjau dari segi sasarannya, dalam hukum administrasi negara dikenal ada dua jenis sanksi, yaitu sanksi reparatoir dan sanksi punitif. Sanksi reparatoir adalah sanksi yang diberikan sebagai reaksi atas pelanggaran norma, yang ditujukan untuk mengembalikan pada kondisi semula sebelum terjadi pelanggaran. Sedangkan sanksi punitif adalah sanksi yang semata-mata ditujukan untuk memberikan hukuman pada seseorang. Selain itu ada juga yang disebut sebagai sanksi regresif, yaitu sanksi yang diterapkan sebagai reaksi atas ketidak patuhan.

\section{Simpulan dan Saran}

\section{SIMPULAN}

1. Pertanggungjawaban administrative pemerintah dalam pengelolaan lingkungan hidup yang tidak sesuai dengan aspirasi masyarakat, dapat berupa pertanggungjawaban administrasi, perdata maupun pidana. Pertanggungjawaban 
pemerintah dari administrasi

Berdasarkan keputusan

tersebut.asarkan UU No. 9

tahun 2004 tentang Perubahan

UU No. 5 tahun 1986 tentang

PTUN Berkaitan dengan hal itu tanggungjawab pemerintah dalam pengambilan keputusannya tidak sesuai dengan aspirasi masyarakat dan menyebabkan kerugian atau luka berat dan/atau meninggal dapat dituntut secara hukum pidana. Hal itu diatur dalam Pasal 111 dan Pasal 112 UU No. 32 Tahun 2009 tentang PPLH,

2. Akibat hukum Administratif terhadap pemerintah atas keputusan dalam pengelolaan lingkungan hidup yang tidak sesuai dengan partisipasi masyarakat. UUPPLH No. 32 Tahun 2009, menyediakan Jalur hukum, administrasi, jalur hukum perdata dan jalur hukum pidana, penyelesaian diluar sidang pengadilan yang diatur dalam Pasal 85, Pasal 86 dan di pengadilan terkait ganti rugi, pemulihan lingkungan dan
38

tindakan lain. Berkaitan dengan Akibat hukum pemerintah dalam hal keputusannya tidak sesuai aspirasi masyarakat dalam hukum lingkunganhak gugat diatur dalam Pasal 91 dan Pasal 92 UUPPLH No. 32 Tahun 2009, tentang Hak gugat masyarakat yang tergabung dalam Organisasi Lingkungan Hidup dan Pasal 93 UUPPLH memberikan hak setiap orang dalam masyarakat dapat mengajukan gugatan administrasi terhadap keputusan pemerintah.

\section{SARAN}

1. Perkembangan pelayanan public pemerintah terhadap masyarakat makin modern masyarakatnya maka tuntutan berbagai aspek kehidupan makin komplek pula. Oleh karena itu pemerintah dituntut bekerja secara cermat, hati-hati, berlandaskan hukum, serta kebijakan yang sesuai dengan prinsip keadilan dengan berpedoman pada Asas-asas Umum Pemerintahan yang Baik harus terus ditingkatkan jika tidak ingin masyarakat

meminta 
pertanggungjawaban

secara

administrasi, perdata maupun

pidana.

2. Apabila pemerintah bertindak tidak sesuai dengan aturan hukum yang berlaku dan tidak sesuai dengan kepantasan dalam menjalankan kebijakannya sehingga menimbilkan kerugian bagi masyarakat tentu dapat diminta pertanggungjawaban baik secara administrasi, perdata maupun pidana. Oleh karena itu maka pemerintah harus bertindak secara hati-hati dalam menjalankan aturan, taat pada aturan serta taat pada asas hukum yang berlaku.

\section{Daftar Pustaka}

\section{Buku}

Hikmat Ramdhan,Yusran, 2003, Pengelolaan Sumber Daya Alam Dan Otonomi Daerah, Perspektif Kebijakan Dan

Evaluasi Ekonomi, Alqaprint Jatinangor.

K.C. Wheare, 1975, Modern Constitution, Oxford University Press London, New York, DSK.
39

Otto Soemarwoto, 1999, Analisis Mengenai Dampak Lingkungan, Gadjah Mada University Press, Cetakan Kedelapan, Yogyakarta.

Philipus M, Hadjon , 1987, Perlindungan Hukum Bagi Rakyat Indonesia, Penerbit Bina Ilmu, Surabaya,

Pitana,2004, Memperjuangkan

Otonomi Daerah :Mencegah Sandyakalaning Pariwisata Bali, Pustaka Bali Post, Denpasar.Sudi

Fahmi,2013,“Asas Tanggung Jawab Negara Sebagai Dasar Pelaksanaan Perlindungan dan Pengelolaan Lingkungan Hidup", Jurnal Hukum.

Rachmadi Usman, 2003

Pembaharuan Hukum

Lingkungan Nasional, Bandung:

Citra Aditya Bakti, Emil Salim, dalam Gatot P Soemartono, 1997, Mengenal Hukum Lingkungan Indonesia, Sinar Grafika, Jakarta Rahardjo, Satjipto, 1982, Aneka Persoalan Hukum dan Masyarakat, Alumni, Bandung. 
Jurnal Hukum Saraswati (JHS) Volume. 03, Nomor 02, (2021)

ISSN (Cetak) : 2715-758X ISSN (Online): 2720-9555

DOI: https://doi.org/10.36733/jhshs.v2i2

https://e-journal.unmas.ac.id/index.php/JHS

\section{Jurnal}

Dyah Adriantini Sintha Dewi, 2012,

“ Konsep Pengelolaan

Lingkungan Hidup, Menuju

Kemakmuran Masyarakat",

Jurnal Fakultas Hukum, Vol. 1

No. 1 Universitas

Muhammadiyah Magelang .

Kartono,2009, Penegakan Hukum

Lingkungan Administratif

Dalam Undang-Undang

Perlindungan dan Pengelolaan

Lingkungan Hidup, Jurnal

Dinamika Hukum, Vol.09 No.

3, Purwekerto : FH UNSOED,

Sudi Fahmi,2013, “Asas Tanggung

Jawab Negara Sebagai Dasar

Pelaksanaan Perlindungan dan

Pengelolaan Lingkungan

Hidup”, Jurnal Hukum, Vol. 18

No. 2 April, Ohni Najwan,

2012,"Perlindungan dan

Pengelolaan Lingkung-an

Hidup dJalam Perspektif

Hukum Islam”, Inovatif: Jur-

nal Ilmu Hukum, Vol. 2 No. 4.

Sutrisno, 2013, “Politik Hukum

Perlindungan dan Pe-

ngelolaan Lingkungan Hidup",

Jurnal Hukum, No. 3 Vol. 18

Juli 2013, FH UII,

40

Soedjono D, 1979, Pengaturan Hukum

Terhadap

Lingkungan Akibat Industri,

Bandung : Alumni, John Cohen and Norman Uphoff,1980, Participation's place in rural development: Seeking clarity through specificity"World

Development, Volume 8, Issue 3 